\title{
ACCUMULATION OF SOLAR RADIATION DEPENDING ON TYPE OF SURFACE IN THE URBAN ENVIRONMENT OF THE CITY NITRA
}

\author{
KATARÍNA BAHNOVÁ, ZDENKA RÓZOVÁ
}

Department of Ecology and Environmental Sciences, Faculty of Natural Sciences, Constantine the Philosopher University in Nitra, Trieda A. Hlinku 1, 94974 Nitra, Slovak Republic; e-mail: katarina.bahnova@ukf.sk, zrozova@ukf.sk

\begin{abstract}
Bahnová K., Rózová Z.: Accumulation of solar radiation depending on type of surface in the urban environment of the city Nitra. Ekológia (Bratislava), Vol. 34, No. 4, p. 392-402, 2015.

The diversity of active surfaces in urban environment is an alarming element of microclimatic conditions at the time of positive energy balance. The accumulation of solar and reflected radiation are forming local climate - microclimate. Vegetation areas in the urban environment have the capability to eliminate extreme demostrations of local climate. The impact of transpiration causes an increase in the relative air humidity, reducing the effect of solar radiation. The result is the elimination of surface temperature in vegetation. The aim of this study is to evaluate the potentiality of accumulation of solar radiation depending on the vegetation structure and the type of surface in research areas A1-B1-C1, A2-B2-C2 between intervals 6:30 a.m.-12:30 p.m., 12:30 p.m.-9:30 p.m. The legwork ran in summer period June-August 2013 in residential area Chrenova 1 in the city Nitra.
\end{abstract}

Key words: microclimate, surface temperature, vegetation structure.

\section{Introduction}

According to Wardoyo et al. (2011), the urban environment is specific to hard surface, typical urban geometry, vegetation areas and variability of surface materials. These factors form and influence microclimate. For every active surface, it is typical that there is a transformation of the energy of the shortwave radiation to the thermal energy. A part of this energy goes to sub base of active surface and vice versa. The active surface is the main climatic factor (Středová et al., 2011). Vegetation plays a significant role in the formation of microclimate and thermal comfort. The surface temperature of vegetation influences the thermal balance through the blazing change (Scudo et al., 2002). Different types of surfaces in the urban environment have different impacts on vegetation. The outflow and sedimentation change, depending on the type of material (Godefroid, Koedam, 2004). Miller and Hobs (2002) point out to possibilities of modeling specific area changes in the urban environment. Solar radiation forms the climatic regime of the Earth and influences the environment. The total solar radiation impinging on the surface of the Earth is global radiation. Global radiation has two components - direct and diffuse radia- 
tion (Chmelík, Pribulová, 2005). Tree vegetation uses $2 \%$ of solar energy on photosynthesis, $60-80 \%$ is absorbed by leaves and $5-15 \%$ is reflected back to space. The rest of the solar energy goes through leaves. A certain amount of radiation is used for warming up the particular parts of a tree. Trees with thin crowns can receive $60-80 \%$ of solar radiation. Through the trees with compact crowns penetrates $2-3 \%$ of solar radiation (Pauditšová, Reháčková, 2006). Albedo is the difference between absorbed and issued heat. Plants have value of albedo that is higher compared with compact areas. The values of albedo differ depending on the type of vegetation and surface. Vegetation generally has value of albedo $15-30 \%$, conifers $10-20 \%$ and dry soil $20-30 \%$. Thermal balance is influenced by the level of transparency of vegetation (density of crown, size of leaves and their orientation) (Pauditšová, Reháčková, 2006). In the urban environment are large concentration of surfaces that are strongly overheated and have large thermal capacity. The result is the accumulation of heat in the city environment (Hudeková, 2012). The temperature of the active surface directly infulences the thermal conditions on the ground and the marginal layer of the atmosphere (Středová et al., 2011). Different thermal characteristic of the active surfaces lead to increased heat absorption during the period of positive energy balance. Due to this modification, the built-up areas can be warmer than the surrounding land. According to Oke (1997), the specific thermal conditions are related to albedo and air pollution. Vegetation areas do not accumulate heat. After the opening of the stomata and during assimilation, the temperature of stomata matches the air temperature or drops down under this temperature (Slováková, Mistrík, 2007). According to Small and Miller (2010), vegetation influences the city conditions of the environment. Vegetation areas have an impact on the energy demand and the formation of thermal heat islands. In certain conditions, plants directly under the sun overheat as well, but this is just short-term overheating, because the evaporation of water from the leaves decreases the temperature of

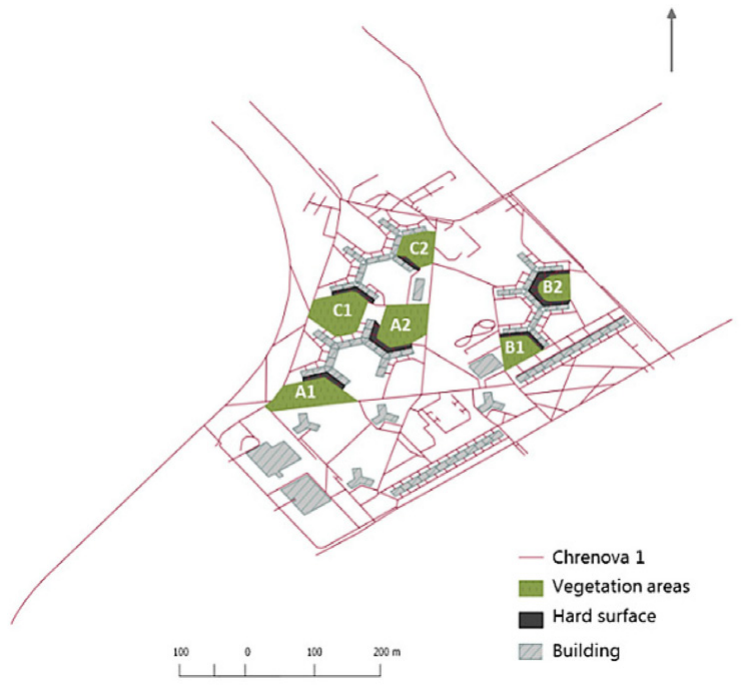

Fig. 1: Research areas assimilating organs, when they are removed from direct sun. Leaves close their stomata to prevent excessive evaporation, which causes even more overheating of leaves. It is important to mention that overheated dry soil, asphalt, concrete, walls of the buildings, tin roofs, or body shells of cars radiate the heat even though the sun is not shining (Čaboun, 2008). The formation of thermal conditions in built-up areas is related to specific characteristics of the urban environment. In the urban environment, there is a change of geometry of an active surface. The expansion of active surface and vertical surfaces is also significant (Voogt, Oke, 2003). 


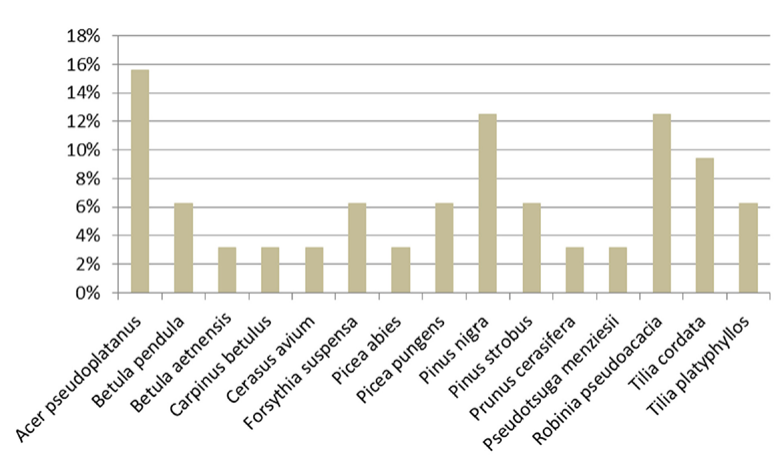

Fig. 2. Percentage of types of vegetation in vegetation area - Locality A1.

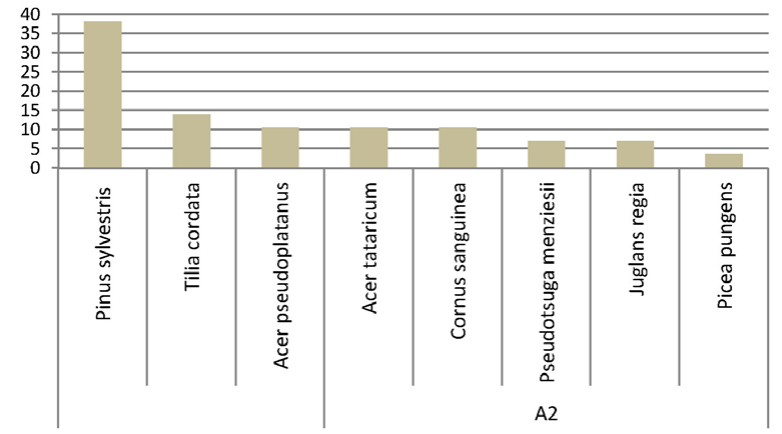

Fig. 3. Percentage of types of vegetation in vegetation area - Locality A2.

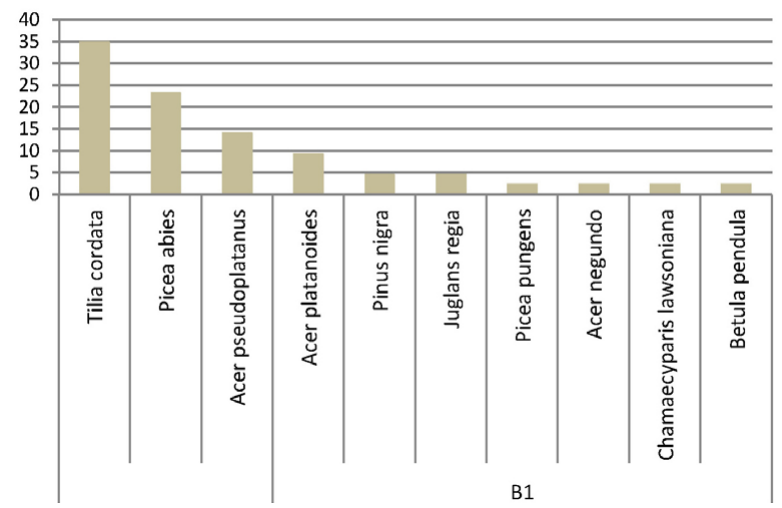

Fig. 4. Percentage of types of vegetation in vegetation area - Locality B1.

\section{Material and methods}

The legwork was accomplished in residential area of Chrenova 1 . The selected localities consisted of three apartment complexes - A,B,C. In apartment complex A - localities A1, A2; in apartment complex B - localities B1, B2; in apartment complex C - localities C1, C2. Research areas include vegetation area, hard surface and block of flat (Fig. 1).

In research areas were accomplished the measurments:

1.in vegetation area - with touch probe and $2 \mathrm{~m}$ above the surface 2.on hard surface - with touch probe and $2 \mathrm{~m}$ above the surface

\section{Structure of vegetation areas}

Locality A1: The vegetation in the locality A1 is bilayer with 50 trees. The monitoring point is located in dense and relatively closed canopy of 26 trees with continuity on the open lawn. The highest part has the type Acer pseudoplatanus - 16\% (Fig. 2).

Locality A2: The vegetation in the locality A2 is three-layered with 33 trees; it is structured into five formations with a central lawn. The vegetation area is open to the inside of residential area. The monitoring point is located in sparse vegetation with 7 trees. The highest percentage has $\mathrm{Pi}$ nus sylvestris - 38\% (Fig. 3).

Locality B1: The vegetation in the locality B1 is three layered with 46 trees. The trees are organized into three small clusters on the left side. In the middle of the vegetation area is the lawn with solitaire tree. The monitoring point is located in vegetation with a dense canopy of crowns with 9 trees. The highest percentage has Tilia cordata-34.9\% (Fig. 4).

Locality B2: The vegetation in area B2 is three layered. It is organized into two clusters, with a dense canopy of crowns. The number of trees in the vegetation area is 11 . The monitoring point is located in the central lawn near the children's playground. The 
highest percentage has Pseudotsuga menziesi-35.8\% (Fig. 5).

Locality C1: The vegetation in the locality $\mathrm{C} 1$ is three layered with 68 trees. The tree vegetation is organized into five clusters. The lawn is open near the river Nitra. The monitoring point is located in the cluster of three trees with a sparse canopy of crowns. The highest percentage has Juglas regia - $42.8 \%$ (Fig. 6).

Locality C2: The vegetation area in the locality $\mathrm{C} 2$ is a typically bounded area by inside of the residential area. In the vegetation area are 22 trees organized into five clusters with a sparse canopy of crowns. The monitoring point is located in the central lawn. The highest percentage has Taxus baccata, Pseudotsuga menziesii, Tilia cordata - 25\% (Fig. 7).

\section{Measurements in research areas}

In research areas $\mathrm{A} 1, \mathrm{~A} 2, \mathrm{~B} 1, \mathrm{~B} 2$, $\mathrm{C} 1, \mathrm{C} 2$ were accomplished measurements with Anemometer TSI Veloci Calc 9565 - P; it is a method of surface thermal monitoring. Twenty measurements were made at 3-second intervals at both the monitoring points for statistical evaluation.

Monitoring of microclimatic factors: 1. air temperature $(2 \mathrm{~m}$ above the surface)

2. surface temperature (with touch probe)

3. relative humidity ( $2 \mathrm{~m}$ above the surface).

Measured values of microclimatic factors during the summer we evaluated with Statistica 7. We used the analysis of variance (ANOVA) one-way and Tukey HSD test (honest significant difference test ).

\section{Results}

The aim of this study is to evaluate the capability of accumulation of solar radiation depending on the structure

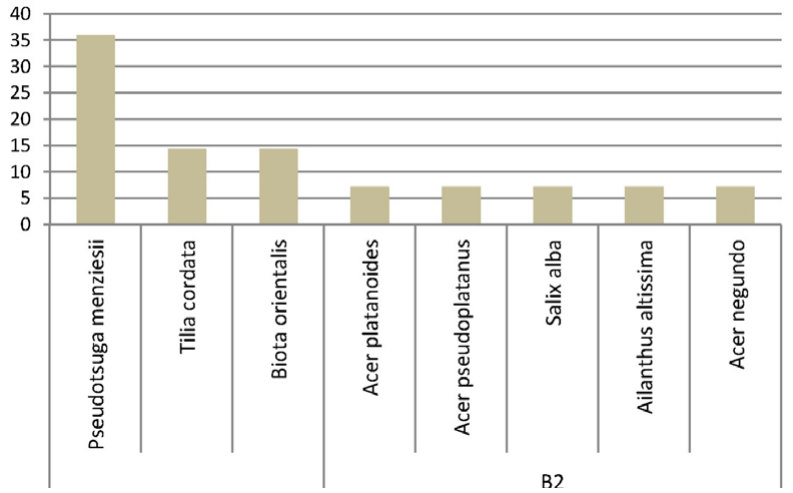

Fig. 5. Percentage of types of vegetation in vegetation area - Locality B2.

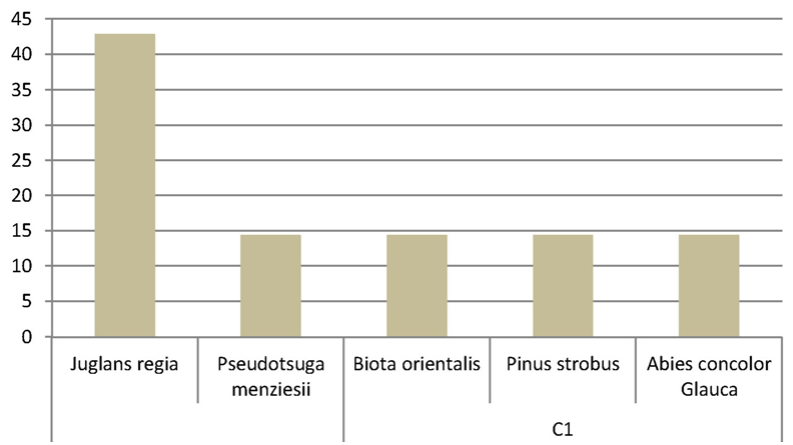

Fig. 6. Percentage of types of vegetation in vegetation area - Locality C1.

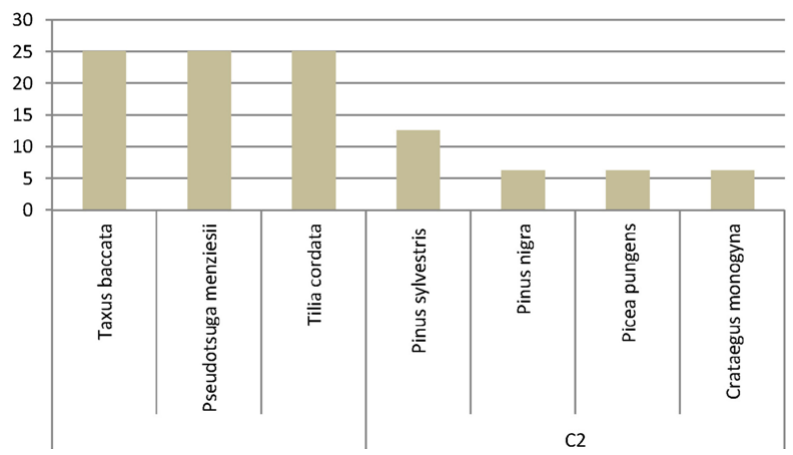

Fig. 7. Percentage of types of vegetation in vegetation area - Locality C2. 
of vegetation area and the form of surface in the research areas A1-B1-C1, A2-B2-C2 between intervals $-6: 30$ a.m. -12:30 p.m., 12:30 p.m.-9:30 p.m. The legwork vas accomplished during the summer June - August 2013 (Table 1) in residential area of Chrenova 1 in city Nitra.

$\mathrm{T}$ a b le 1 . Time of measurements in summer period.

\begin{tabular}{|l|c|c|c|}
\hline MONTH & JUNE & JULY & AUGUST \\
\hline \multirow{3}{*}{ TIME } & 5:40 a.m. & 6:00 a.m. & 6:15 a.m. \\
\cline { 2 - 4 } & 12:30 p.m. & 12:30 p.m. & 12:30 p.m. \\
\cline { 2 - 4 } & $9: 30$ p.m. & $9: 45$ p.m. & $9: 00$ p.m. \\
\hline
\end{tabular}

In Fig. 8 are the significant differences in surface temperature in the interval 6:30 a.m. - 12:30 p.m. between the localities A2-B2 and A2-C2. During the time of positive energy balance was the difference of surface temperature on the research area $\mathrm{A} 2-8.95{ }^{\circ} \mathrm{C}$; on the research area $\mathrm{B} 2-13.49^{\circ} \mathrm{C}$; on research area $\mathrm{C} 2-14 ; 35^{\circ} \mathrm{C}$. The vegetation area $\mathrm{A} 2$ had 33 trees. The measurement point is located in a sparse canopy of vegetation with 7 trees. The surface temperature on research area $\mathrm{A} 2$ was $26.3^{\circ} \mathrm{C}$ at the time $12: 30$ p.m. It was also the lowest value. The significant value was the relative air humidity at the time $6: 30 \mathrm{a} . \mathrm{m}$. The maximum relative air humidity was $76 \%$ on the research area A2. The degree of saturation of air by water vapour in vegetation depends on the quantity and the function of the vegetation. Significant is the relation between humidity and air temperature, higher humidity = lower temperature. The lowest value of relative air humidity was $69 \%$ in locality B2 at the time 6:30

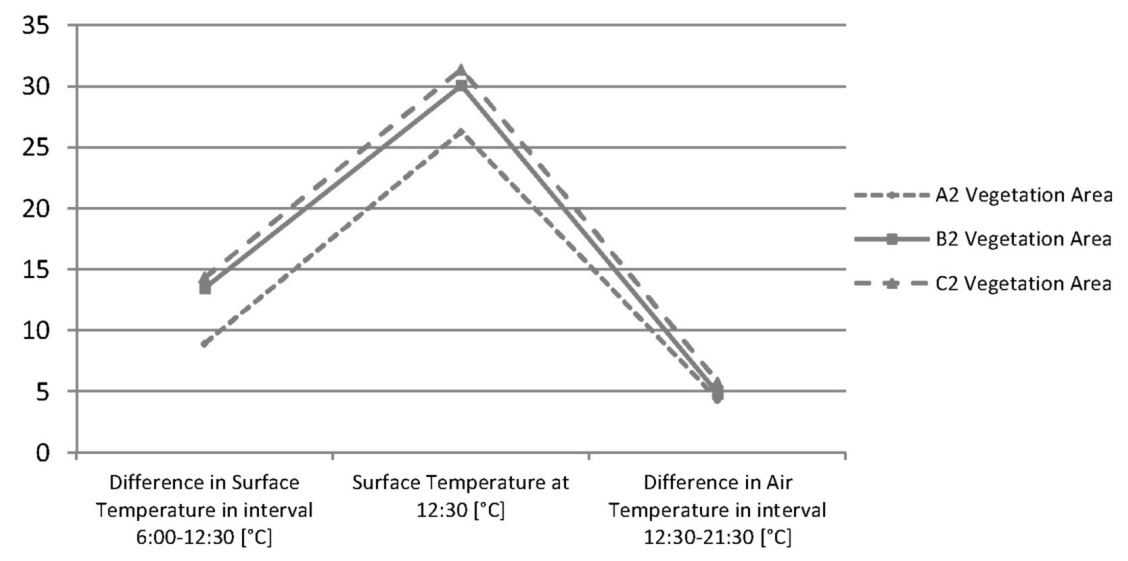

Fig. 8. Difference in surface temperature $\left({ }^{\circ} \mathrm{C}\right)$ in vegetation areas $\mathrm{A} 2, \mathrm{~B} 2, \mathrm{C} 2$ with north-east orientation depending on vegetation structure in interval 6:00 a.m.-12:30 p.m.; surface temperature $\left({ }^{\circ} \mathrm{C}\right)$ in vegetation areas $\mathrm{A} 2, \mathrm{~B} 2, \mathrm{C} 2$ with north-east orientation depending on vegetation structure at $12: 30$ p.m.; difference in air temperature $\left({ }^{\circ} \mathrm{C}\right)$ in vegetation areas A2, B2, C2 with north-east orientation depending on vegetation structure in interval 12:30 p.m. $-9: 30$ p.m.. 
a.m.. The localities B2, C2 are dominated by open lawns with sparse vegetation. During the time of positive energy balance, these areas accumulate more solar radiation due to which the surface temperature rises. The difference of surface temperature between vegetation area with trees and the lawns without trees was $5-6^{\circ} \mathrm{C}$ in the interval 6:00 a.m. $-12: 30$ p.m.. The structure of vegetation was a significant factor between localities A2-B2 (Tukey HSD test, $\mathrm{p}=0.04, \mathrm{p}<0.05$ ), and localities A2-C2 (Tukey HSD test, $\mathrm{p}=0.01$ ). The significant statistic value in air temperature was evaluated in the interval 12:30 p.m.-9:30 p.m. (Tukey HSD test, $\mathrm{p}=0.02, \mathrm{p}<0.05)$.

In Fig. 9 is the evaluated difference of temperature in monitoring point of hard surface between localities A1, B1, C1. We evaluated the surface temperature at the time 12:30 p.m. and the difference between air and surface temperature in the monitoring point of hard surface in the interval 12:30 p.m.- 9:30 p.m. The statistically significant value was the difference of surface temperature between localities A1-B1 in the interval 6:00 a.m.-12:30 p.m., (Tukey HSD test, $\mathrm{p}=0.04, \mathrm{p}<0.05$ ). In the research area $\mathrm{A} 1$, the temperature in the monitoring point of hard surface increased up to $8.12{ }^{\circ} \mathrm{C}$. In the vegetation area $\mathrm{A} 1$ were 50 trees in the dense canopy, after which the hard surface continued. Trees with south-west orientation in the dense canopy provided partial shading on the hard surface during the time of positive energy balance - in the interval 6:00 a.m.-12:30 p.m. The accumulation of solar radiation in this research area was the lowest compared to localities B1 and $\mathrm{C} 1$. Between localities A1-C1 was noticed significant statistical difference of surface temperature at the time 12:30 p.m. (Tukey HSD test $\mathrm{p}=0.02, \mathrm{p}<0.05$ ). The value of surface temperature in the research area $\mathrm{A} 1$ was $25.88^{\circ} \mathrm{C}$, and in the research area $\mathrm{C} 1$ was $30.69^{\circ} \mathrm{C}$ at the time 12:30 p.m. In the interval 12:30 p.m.- 9:30 p.m., we evaluated the cooling effect on the

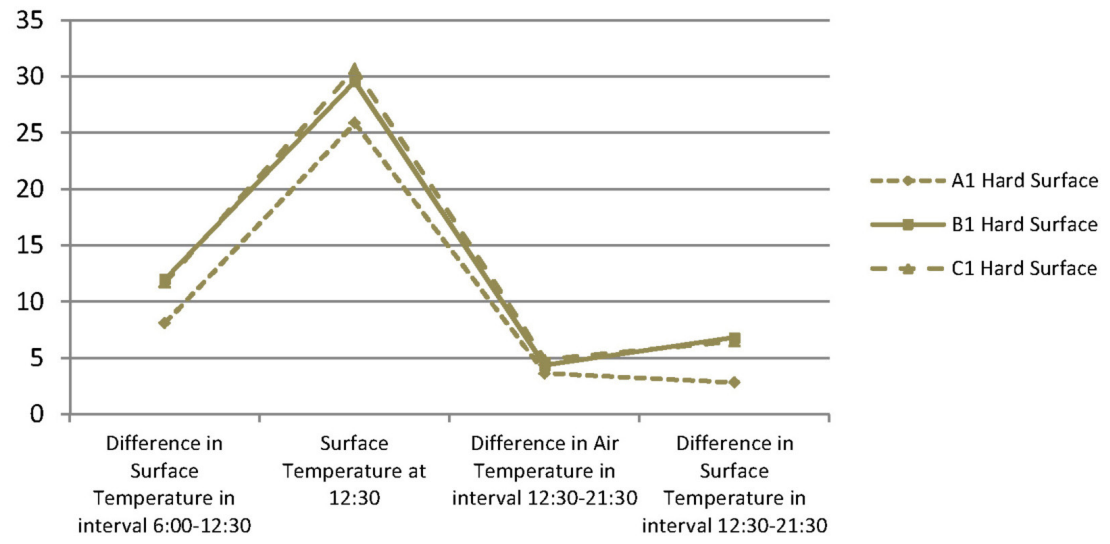

Fig. 9. Difference in surface temperature $\left({ }^{\circ} \mathrm{C}\right)$ on hard surface $\mathrm{A} 1, \mathrm{~B} 1, \mathrm{C} 1$ with south-west orientation in interval 6:00-12:30; surface temperature $\left({ }^{\circ} \mathrm{C}\right)$ on hard surface $\mathrm{A} 1, \mathrm{~B} 1, \mathrm{C} 1$ with south-west orientation at 12:30; difference in air temperature $\left({ }^{\circ} \mathrm{C}\right)$ on hard surface - localities A1, B1, C1 with south-west orientation in interval 12:30 p.m. $-9: 30$ p.m.; difference in surface temperature $\left({ }^{\circ} \mathrm{C}\right)$ on hard surface - localities A1, B1, C1 with south-west orientation in interval 12:30 p.m.-9:30 p.m.. 
hard surface temperature among localities A1, B1, C1. The lowest difference of surface temperature in the interval 12:30 p.m. $-9: 30$ p.m. was in the locality $\mathrm{A} 1-2.83{ }^{\circ} \mathrm{C}$. The difference of surface temperature in the locality B1 was $-6.83{ }^{\circ} \mathrm{C}$. In the locality $\mathrm{C} 1$, the difference of surface temperature in the interval 12:30 p.m.-9:30 p.m. was $6.51{ }^{\circ} \mathrm{C}$. Statistical significance was confirmed between localities A1-B1 (Tukey HSD test, $\mathrm{p}=0.0002$, $\mathrm{p}<0.001$ ) and localities A1-C1 (Tukey HSD test, $\mathrm{p}=0.0005, \mathrm{p}<0.001$ ). In the interval 12:30 p.m.-9:30 p.m., we evaluated the cooling effect - air temperature above the hard surface among localities A1, B1, C1. The lowest difference in air temperature above hard surface was in the locality A $1-3.63^{\circ} \mathrm{C}$. In this locality were 50 trees with a dense canopy of crowns (Fig. 2). During the time of negative energy balance, the air temperature cooled down the least in the locality A1. It was a result of the vegetation with the transpiration impact that maintained the air temperature. The vegetation area regulates the maximum differences in vegetation and its surroundings when the sun is not shining. We confirmed the significant statistical difference in air temperature above the hard surface between localities A1-C1 (Tukey HSD test, $\mathrm{p}=0.02, \mathrm{p}<0.05$ ).

In Fig. 10 are the compared values of the surface temperature among localities A1, B1, $\mathrm{C} 1$ in the monitoring point of the vegetation area and the hard surface at the time 12:30 p.m.. The lowest temperature of the surface in the vegetation area was measured in the locality $\mathrm{A} 1-26.04^{\circ} \mathrm{C}$, and the highest temperature in the locality $\mathrm{B} 1-26.7^{\circ} \mathrm{C}$. The highest surface temperature on the hard surface was measured in the locality $\mathrm{C} 1-30.68{ }^{\circ} \mathrm{C}$. The difference in surface temperature between the monitoring points of vegetation area and the hard surface was $4.3^{\circ} \mathrm{C}$. In the monitoring point of the hard surface was observed the lowest of surface temperature in the locality $\mathrm{A} 1-25.88^{\circ} \mathrm{C}$. The minimum difference in surface temperature between monitoring points of the vegetation area and the hard surface of the locality A1 was $0.16^{\circ} \mathrm{C}$. The locality A1 had the maximum number of trees among all the research areas.

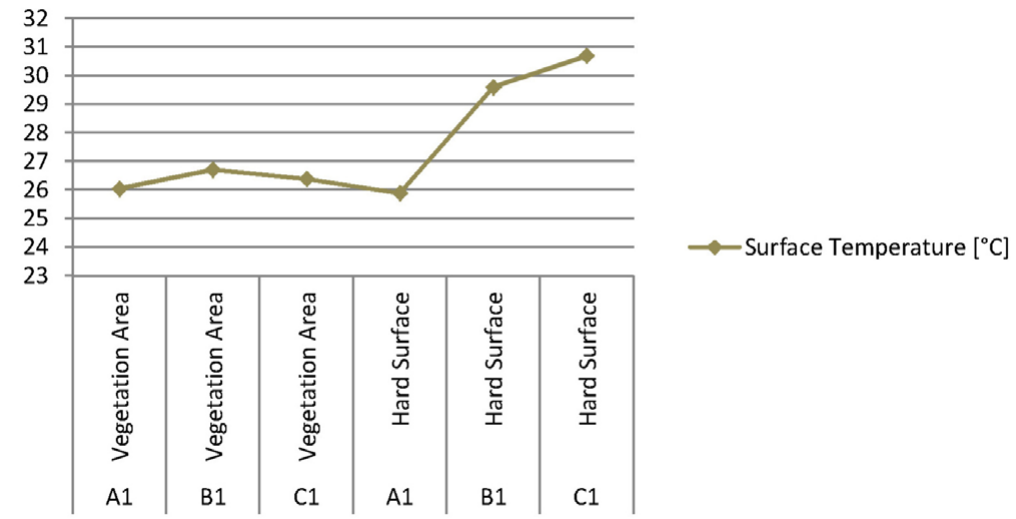

Fig. 10. Difference in surface temperature $\left({ }^{\circ} \mathrm{C}\right)$ in vegetation areas - localities $\mathrm{A} 1, \mathrm{~B} 1, \mathrm{C} 1$ and hard surface - localities $\mathrm{A} 1, \mathrm{~B} 1, \mathrm{C} 1$, with south-west orientation in summertime at 12:30 p.m.. 
In Fig. 11 are the compared values of the surface temperature among localities A2, B2, C2 in the monitoring points of the vegetation area and the hard surface at the time 12:30 p.m. The lowest surface temperature in monitoring point vegetation area was measured in the locality A2 $-26.3^{\circ} \mathrm{C}$ and the highest surface temperature in the locality $\mathrm{C} 2-31.56^{\circ} \mathrm{C}$. The highest surface temperature $-35.42^{\circ} \mathrm{C}$ in monitoring point of hard surface was measured in the locality $\mathrm{B} 2$ and the lowest surface temperature in the locality $\mathrm{A} 2-31.31^{\circ} \mathrm{C}$. The highest difference in surface temperature between the vegetation area and the hard surface was $-5.32{ }^{\circ} \mathrm{C}$ in the locality $\mathrm{B} 2$.

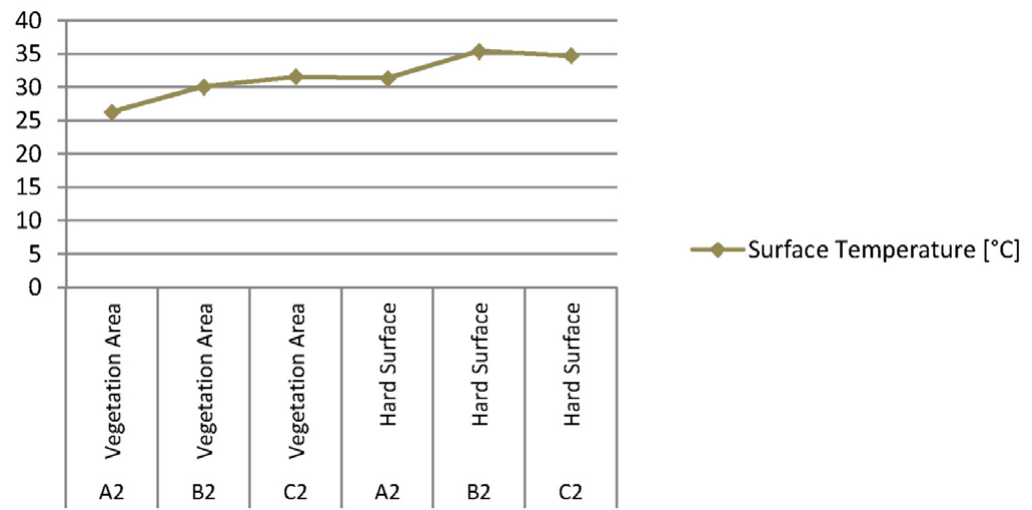

Fig. 11. Difference in surface temperature $\left({ }^{\circ} \mathrm{C}\right)$ in vegetation area - localities A2, B2, C2 and hard surface - localities A2, B2, C2 with north-east orientation in summertime at 12:30 p.m..

In Table 2 are evaluated the impact of orientation towards cardinal points in surface temperature in the measurement point in vegetation area for all localities - A1, B1, C1 with south-west orientation, localities A2, B2, C2 with north-east orientation. Statistically significant were differences in surface temperature depending on the orientation between localities A1-C2 (Tukey HSD test, $\mathrm{p}=0.007, \mathrm{p}<0.01$ ), localities B1-C2 (Tukey HSD test, $\mathrm{p}=0.03$, $\mathrm{p}<0.05$ ) and localities C1-C2 (Tukey HSD test, $\mathrm{p}=0.01$ ).

T a b l e 2. Values of surface temperature $\left({ }^{\circ} \mathrm{C}\right)$ in vegetation areas $\mathrm{A} 1, \mathrm{~A} 2, \mathrm{~B} 1, \mathrm{~B} 2, \mathrm{C} 1, \mathrm{C} 2$ depending on orientation in summertime at 12:30 p.m.

\begin{tabular}{|l|l|c|c|c|c|c|c|}
\hline \multicolumn{7}{|c|}{ Tukey HSD test; Vegetation Area - 12:30 Surface Temperature } \\
\hline & Locality & $\{\mathbf{1}\}-\mathbf{2 6 . 0 4 2}$ & $\{\mathbf{2}\}-\mathbf{2 6 . 3 0 3}$ & $\{\mathbf{3}\}-\mathbf{2 6 . 7 1 1}$ & $\{\mathbf{4}\}-\mathbf{3 0 . 1 0 2}$ & $\{\mathbf{5}\}-\mathbf{2 6 . 3 8 3}$ & $\{\mathbf{6}\}-\mathbf{3 1 . 5 6 6}$ \\
\hline 1 & A1 & & 0.999983 & 0.998427 & 0.125630 & 0.999939 & $\mathbf{0 . 0 0 7 9 5 5}$ \\
\hline 2 & A2 & & & 0.999852 & 0.158374 & 1.000000 & $\mathbf{0 . 0 1 0 2 6 8}$ \\
\hline 3 & B1 & & & & 0.304504 & 0.999953 & $\mathbf{0 . 0 3 2 5 8 3}$ \\
\hline 4 & B2 & & & & & 0.186331 & 0.940067 \\
\hline 5 & C1 & & & & & & $\mathbf{0 . 0 1 3 6 8 9}$ \\
\hline 6 & C2 & & & & & & \\
\hline
\end{tabular}


In Table 3 are evaluated the impact of orientation towards cardinal points in the surface temperature in the measurement point on hard surface for all localities, A1, B1, C1 with south-west orientation, localities A2, B2, C2 with north-east orientation. Statistically significant were differences in the surface temperature depending on the orientation between localities A1-B2 (Tukey HSD test, $\mathrm{p}=0.0004, \mathrm{p}<0.001$ ) and A1-C2 (Tukey HSD test, $\mathrm{p}=0.0008$, $\mathrm{p}<0.001)$.

$\mathrm{T} \mathrm{a} \mathrm{b} 1$ e 3. Values of surface temperature $\left({ }^{\circ} \mathrm{C}\right)$ on hard surface-localities A1, A2, B1, B2, C1, C2 depending on orientation in summertime at 12:30 p.m.

\begin{tabular}{|l|l|c|c|c|c|c|c|}
\hline \multicolumn{7}{|c|}{ Tukey HSD test; Hard Surface - 12:30 Surface Temperature } \\
\hline & Locality & $\{\mathbf{1}\} \mathbf{- 2 5 . 8 8 3}$ & $\{\mathbf{2}\} \mathbf{- 3 1 . 3 1 8}$ & $\{\mathbf{3}\} \mathbf{- 2 9 . 5 9 2}$ & $\{\mathbf{4}\}-\mathbf{3 5 . 4 2 6}$ & $\{\mathbf{5}\} \mathbf{- 3 0 . 6 8 5}$ & $\{\mathbf{6}\} \mathbf{- 3 4 . 7 1 1}$ \\
\hline 1 & A1 & & 0.104098 & 0.497031 & $\mathbf{0 . 0 0 0 4 5 9}$ & 0.212715 & $\mathbf{0 . 0 0 0 8 9 5}$ \\
\hline 2 & A2 & & & 0.961853 & 0.397635 & 0.999686 & 0.582248 \\
\hline 3 & B1 & & & & 0.085179 & 0.995435 & 0.156335 \\
\hline 4 & B2 & & & & & 0.252277 & 0.999529 \\
\hline 5 & C1 & & & & & & 0.402843 \\
\hline 6 & C2 & & & & & & \\
\hline
\end{tabular}

\section{Discussion}

In this study, we evaluated the capability of accumulation of solar radiation depending on the type of surface in city Nitra. The active surfaces in the urban environment are the main microclimatic factors. The microclimatic function of vegetation and monitoring its specific demonstrations is nowadays the current tool for elimination of extreme weather demonstrations, especially in the urban environment. The capability to absorb solar radiation during the time of positive energy balance depends on the vegetation structure, the canopy of trees and the quantity. In Fig. 8, the surface temperature increased by $13.49{ }^{\circ} \mathrm{C}$ in the vegetation area $\mathrm{B} 2$ with the dominant lawn in the interval 6:00 a.m.-12:30 p.m. In the vegetation area $\mathrm{C} 2$, the surface temperature increased by $14.35^{\circ} \mathrm{C}$. In the vegetation area $\mathrm{A} 2$, the monitoring point is located in a sparse canopy of 7 trees. Here the surface temperature increased by only $8.95^{\circ} \mathrm{C}$. We evaluated the statistical significance in surface temperaure depending on the vegetation structure by using ANOVA one-way analysis and Tukey HSD test. According to Caboun, 2008, the way the vegetation modifies direct solar radiation influences the thermal regime. On average, the difference in the surface temperature between the vegetation area with and without trees (with the lawn) was $5-6^{\circ} \mathrm{C}$. The correlation between vegetation structure and surface temperature was confirmed by the authors (Keresztesová et al., 2013). They recorded the lowest surface temperature during summertime in city park of Nitra. The changes of relative air humidity are related to the air temperature. According to Tužinský, 2002, is higher relative air humidity in the tree vegetation, in the part of trunk - the morning type of humidity. The highest relative air humidity is in the surface of the soil. It was confirmed in the vegetation area A2 with the tree vegetation. Here the value of relative air humidity was $76 \%$ at the time $6: 30$ a.m. Compared with the value of relative air humidity in the vegetation area B2, without the trees vegetation, it was only $69 \%$. 
The vegetation area $\mathrm{A} 1$ is the locality with the maximum of trees - 50 species in the dense canopy of crowns. We monitored the surface temperature on the hard surface near the vegetation area (Fig. 1). Trees with the dense canopy provide partial obscuration of the hard surface at the time of positive energy ballance - interval 6:30 a.m.-12:30 p.m. Here we evaluated the lowest accumulation of the surface temperature compared with localities B1 and $\mathrm{C} 1$. Between localities A1-C1, at the monitoring point of the hard surface, we evaluated the significant statistical difference in the factor of surface temperature at the time 12:30 p.m. too. In the locality $\mathrm{A} 1$, it was $25.88^{\circ} \mathrm{C}$, and in the locality $\mathrm{C} 1$, it was $30.69^{\circ} \mathrm{C}$, (Tukey HSD test, $\mathrm{p}=0.02, \mathrm{p}<0.05)$. The lowest cooling effect of air temperature we evaluated was in locality A1 at the time of negative energy balance (the difference of air temperature in the interval 12:30 p.m. $-9: 30$ p.m. $-3.63{ }^{\circ} \mathrm{C}$ ). A significant factor is the ability of vegetation with the transpiration impact to maintain the air temperature. It means to regulate the maximum differences in the vegetation and the surroundings, hard surface, when sun is not shining.

\section{Conclusion}

The aim of this study was to evaluate the capability of accumulation of solar radiation depending on vegetation structure and quality of areas A1-B1-C1, A2-B2-C2 in intervals 6:00 a.m.-12:30 p.m., 12:30 p.m.-9:30 p.m. We accomplished the legwork in summertime, JuneAugust 2013 in residential area Chrenova 1 by using methods of the surface thermal monitoring. We evaluated the measurements values by using the ANOVA one-way analysis and Tukey HSD test in the software Statistica 7. The relationships between the vegetation structure and the surface temperature were shown as statistically significant. The accumulation of the solar radiation on vegetation area without the trees was higher - on average by $6{ }^{\circ} \mathrm{C}$. The factor of relative air humidity was significant in the locality A1 - with the largest amount of species in the dense canopy of crowns. Research results refer to the ability of vegetation to positively influence microclimate in the urban environment. Quantification of the measurement data, statistical analysis and its generalization will provide in the future possibilities of how to solve problems related to extreme demonstrations of climatic changes in the urban environment.

\section{Acknowledgements}

This study is the result of the project implementation: Environmental aspects of the urban environment (Environmentálne aspekty urbanizovaného prostredia) ITMS 26220220110 supported by the Research \& Development Operational Program funded by the ERDF.

\section{References}

Čaboun, V. (2008). Vegetation impact on decreasing of surface temperature and air temperature during the extreme heat (in Slovak). In J. Rožnovský \& T. Litschmann (Eds.), Bioklimatologické aspekty hodnocení procesů v krajině. Mikulov, 9.- 11.9.2008.

Chmelík, M. \& Pribulová A. (2005). Solar UV radiation significantly influences theenvironment (in Slovak). Enviromagazín, 3, 28-29.

Godefroid, S. \& Koedam N. (2004). Interspecific variation in soil compactionsensitivity among forest floor species. Biol. Conserv., 119, 207-217. DOI: 10.1016/j.biocon.2003.11.009. 
Hudeková, Z. (2012). After-effects of climate changes in urban environment and the urban planning (in Slovak). Online. http://www.urbion.sk/dosledky-zmien-klimy-v-urbanizovanomprostredi-a-uzemne-planovani/

Keresztesová, S., Strelková, M. \& Rózová Z. (2013). Impact of vegetation on surfacetemperature in the city Nitra (in Slovak). In M. Heinrichová \& T. Reháčková (Eds.), Aktuálne problémy krajinnej architektúry a krajinného plánovania (pp. 94-99). Bratislava: Veda, vydavatel'stvo SAV.

Miller, J.R. \& Hobbs R.J. (2002). Conservation where people liveand work. Conserv. Biol., 16, 330-337. DOI: 10.1046/j.1523-1739.2002.00420.x.

Oke, T.R. (1997). Urban climates and global environmental change. In R.D. Thompson \& A.H. Perry (Eds.), Applied climatology: Principles and practice (pp. 273-287). London: Routledge.

Pauditšová, E. \& Reháčková T. (2006). Practical experiences with the evaluation of microclimatic function of vegatation in urban environment (in Slovak). In Sídlo - Park - Krajina IV. Kultúrna vegetácia v sídlach a v krajine (pp. 227-235). Zborník vedeckých prác a referátov. Nitra: SPU.

Scudo, G., Dessi, V. \& Rogora A. (2002). Evaluation of radiant conditions in urban spaces. In M. Nikolopoulou (Ed.), Designing open spaces in the urban environment: a bioclimatic approach (pp. 12-17). Greece: CRES.

Slováková, L. \& Mistrík I. (2007). Physiological processes of plants in stress conditions (in Slovak). Bratislava: Univerzita Komenského.

Small, C.H. \& Miller R.B. (2010). Monitoring the urban environment from space. Digital Cities II.

Středová, H., Bokwa, A, Dobrovolný, P. et al. (2011). Urban microclimate and mesoclimate, stand microclimate (in Czech). Praha: Český hydrometeorologický ústav.

Tužinský, L. (2002). Bioclimatology (in Slovak). Zvolen: Technická univerzita.

Voogt, J.A. \& Oke T.R. (2003). Thermal remote sensing of urban climates. Remote Sens. Environ., 86, 370-384. DOI: $10.1016 /$ S0034-4257(03)00079-8.

Wardoyo, J., Suprapti, A. \& Wediningsih H. (2011). Vegetation configuration as microclimate control strategy in hot humid tropic urban open space. S E N V A R + I S E S E E1-3 December 2008, International seminar in sustainable environment \& architecture. 